\title{
The Effect of Korean Medicine Treatments on Facial Asymmetry: A Case Report
}

\author{
Chan-Young Kwon ${ }^{1,3}$, Hoon-Hui Lee ${ }^{2}$, Yong-Seok Im² \\ 1 Department of Clinical Korean Medicine, Graduate School, Kyung Hee University, \\ ${ }^{2}$ Miall Korean Medicine Clinic, ${ }^{3}$ Yanggu Public Health Center \\ 안면 비대칭에 대한 한의학적 치료의 효과: 증례보고 \\ 권찬영 $^{1,3} \cdot$ 이훈희 $^{2} \cdot$ 임용석 $^{2}$ \\ ${ }^{1}$ 경희대학교 대학원 임상한의학과, ${ }^{2}$ 미올한의원, ${ }^{3}$ 양구보건소
}

\begin{abstract}
Objectives : Despite the applicability of Korean Medicine(KM) treatments for facial asymmetry, no relevant study has been reported. In this case report, we report the effect and safety of KM treatments on facial asymmetry by mandibular lateral displacement. Methods : Three patients suffering from facial asymmetry received twelve KM treatment sessions composed of Motion Style Treatment(MST), Yinyang Balance Appliance(YBA) of Functional Cerebrospinal Therapy(FCST), and Instrument Assisted Soft Tissue Mobilization(IASTM). The photos of each patient were taken before and after the treatment. And four primary reference lines were assessed before and after the treatment. Results : All subjects were improved after KM treatments on photos. However, no statistical significance was observed. Conclusions: This case report is the first to introduce the effect of KM treatments on facial asymmetry. Further well-designed, randomized, placebo-controlled trials are needed to verify these results.
\end{abstract}

Key words : acupuncture, Korean traditional medicine, facial asymmetry

\section{Introduction}

Facial asymmetry means that the size, shape and arrangement of facial components are not coincident with each other in the midline, and in case of severe asymmetry, it may cause problems in functional areas as well as in aesthetic areas ${ }^{1}$. According to the main structure causing asymmetry, facial asymmetry is divided into skeletal asymmetry, tooth asymmetry, muscle asymmetry and functional asymmetry ${ }^{2}$. The functional asymmetry of face can be caused by mandibular displacement due to snaggletooth, unilateral chewing habits, internal derangement of temporomandibular joint(TMI), and so $\mathrm{on}^{3}$. To correct the asymmetry, a variety of orthodontics and orthopedic treatments are considered depending on the age and severity of the asymmetry ${ }^{4}$.

Motion Style Treatment(MST) is a kind of acupuncture treatment that allows the patients to move the treatment site while the needle is inserted, and has been shown to have a significant improvement in temporomandibular disorder (TMD) patients). This suggests the possibility that MST can treat facial asymmetry by helping to correct mandibular displacement.

Received September 6, 2017, Revised September 18, 2017, Accepted September 19, 2017

Corresponding author: Yong-Seok Im

Miall Korean Medicine Clinic, 378, Gangnam-daero, Gangnam-gu, Seoul 06232, Korea

Tel: +82-2-553-7000, Fax: +82-2-6008-7886, E-mail: miall2013@naver.com

(c) This is an open access article distributed under the terms of the Creative Commons Attribution Non-Commercial License (http://creativecommons.org/licenses/ by-nc/4.0) which permits unrestricted non-commercial use, distribution, and reproduction in any medium, provided the original work is properly cited. 
Instrument Assisted Soft Tissue Mobilization(IASTM) is a treatment based on the theory of James Cyriax, which is applied to stiffness and restriction of soft tissues such as muscle fascia using specially designed tools ${ }^{\natural}$. According to a recent systematic review, IASTM significantly improves the range of joint motion in a short period of time ${ }^{7}$. Yinyang Balance Appliance(YBA) of Functional Cerebrospinal Therapy (FCST) is a dental patty which is used to restrain the balance of TMJ and cervical vertebrae ${ }^{8)}$.

In case of functional facial asymmetry, orthodontic treatment should be performed to correct the displaced mandible and to correct the center of the maxilla and mandible ${ }^{4}$. There is a report that facial asymmetry has been improved using occlusal splint, however, there are no studies reporting the effects of KM treatments on facial asymmetry"). In this case report, we treated three cases with facial asymmetry using KM treatments composed of MAT, FCST, and IASTM. It is hypothesized that these KM treatments are effective in improving facial asymmetry without severe adverse event.

\section{Case}

Three patients complaining facial asymmetry were treated by $12 \mathrm{KM}$ treatment sessions in XX clinic from September 2014 to September 2016. All patients agreed to provide clinical information with consent form. This study was conducted in accordance with the Declaration of Helsinki ${ }^{10)}$.

\section{Clinical Characteristics}

The ages of the patients involving two males and one female were 24, 21, and 22, respectively. They did not receive any other treatments for improvement of the facial asymmetry within 6 months before, and did not have dental history related with facial asymmetry, and severe mental illness or internal disease at the first visit.

There was a left mandibular displacement in all patients when a 6-year clinical experienced KM doctor assessed the dental, skeletal, soft tissues and functional structures of the face, suggesting that this displacement may have resulted in functional facial asymmetry. Imbalances of mouth and jaw were found in all patients, and imbalances of mandibular teeth and eye were found in two patients, respectively(Table 1).

\section{Treatment}

The patients were treated by KM treatments 12 times, once every 7 to 10 days for 106, 91, and 110 days, respectively. In every visit, MST and IASTM were applied and the YBA was adjusted.

MST was conducted by single KM doctor who had more than six years of clinical experience. After allowing the patient to lie down in supine position, two single-use stainless steel $0.20 \times 30$ millimeter needles(DongBang acupuncture Inc, Korea) were inserted perpendicularly into unilateral ST7(Hagwan) at a depth of 2 to $3 \mathrm{~cm}$ and unilateral EX-HN5(Taiyang) at a depth of 0.5 to $1 \mathrm{~cm}$ to stimulate masseter and temporalis, respectively, on the side where the deviation occurred. The other same two single-use needles were inserted into bilateral TH17(Yepung) towards the opposite eye at a depth of $3 \mathrm{~cm}$ to stimulate medial and lateral pterygoid. With the needles inserted for 15 minutes, the patient repeatedly performs opening and closing of the mouth at a rate of 15 to 20 times per minute while observing a hand mirror, with caution to ensure that the upper labial frenum meets the lower labial frenum(Fig. 1).

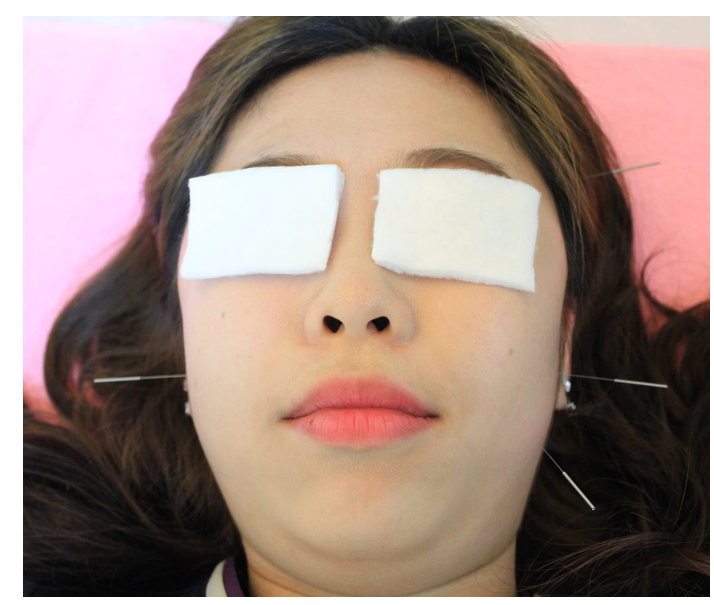

Fig. 1. Motion Style Treatment. Needle insertions on unilateral Hagwan(ST7) and Taiyang (EX-HN5) and bilateral Yepung(TH17) to perform Motion Style Treatment. 
Graston technique, a type of IASTM, was used to relax the soft tissues and restore motion of TMJ. It was conducted by the same KM doctor using Graston tool no.3(Graston Technique LLC, America). To the patient with supine position, the doctor held the tool with his right hand while pushing the muscle belly his left fingertips, and stimulated the muscle by pushing the tool in the direction perpendicular to the muscle fiber. This treatment was applied to unilateral masseter and temporalis on the side where the deviation occurred. And each muscle was treated for 5 minutes, respectively(Fig. 2).

Depending on the balance state, YBA was elaborately made using Exofine Putty Type(GC corporation, Japan), which is a vinyl polysiloxane impression material. Each time the patient visited, the central balance of maxilla and mandible was measured and the YBA was adjusted. Patients were advised to wear this tool for an average of more than 4 hours per day during the treatment period(Fig. 3).

From the day of the treatment initiation, mild cleansing, make-up, and bathing were allowed, however, strenuous exercise, drinking alcohol, and sauna were avoided to prevent inflammation on the treatment site. And during a week after the treatment, massage or strong stimulation on face was avoided, too.

\section{Outcome and Follow Up}

Although facial asymmetry is mainly assessed through photographs, there is a heterogeneity of evaluation even

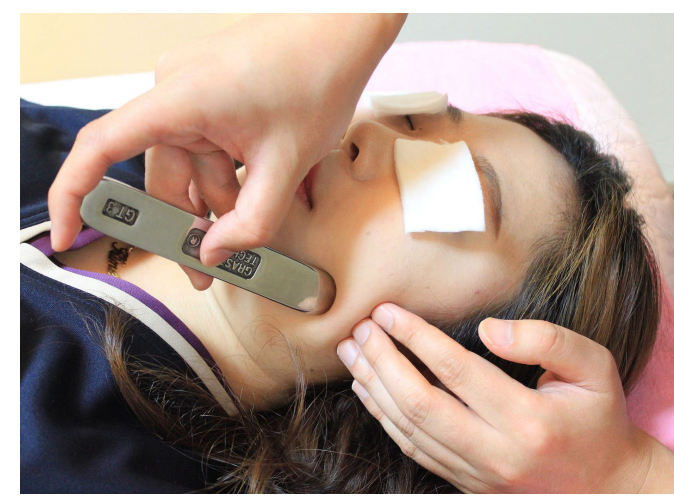

Fig. 2. Graston Technique.

Graston technique using Graston tool no.3(Graston Technique LLC, America). among healthcare providers, as there is no golden standard to analyze them ${ }^{11)}$.

Therefore, we performed assessment by photographing, and tried to obtain a quantitative effect by drawing evaluation lines and calculating the angle of inclination.

Patients were photographed using a DSLR camera EOS5D (Canon, Japan) at before and after treatment ${ }^{12}$.

The evaluator instructed the patient to sit comfortably with his/her waist straight on the seat and to keep his/her mouth closed comfortable. And then, the evaluator took photographs with the camera lens placed in a horizontal position with respect to the patient's face.

The following evaluation lines were drawn from the photographs: (a) line connecting the center of the both upper eyelids; (b) line connecting the both coners of mouth; (c) line connecting the midpoint of upper lip and mentum; and (d) midlines of maxillary teeth and of mandibular teeth. The angles between each evaluation line and the centerline were calculated. We assessed the clinical effect by calculating correction effect. The correction effect was defined as follow.

*Correction effect=|degree of inclination before treatment $\mid-$ |degree of inclination after treatment |

To check and cope with the occurrence of adverse events, patients were advised to contact the healthcare provider immediately if symptoms such as pain, paresthesia, swelling, or dizziness persisted for more than 2 days after treatment.

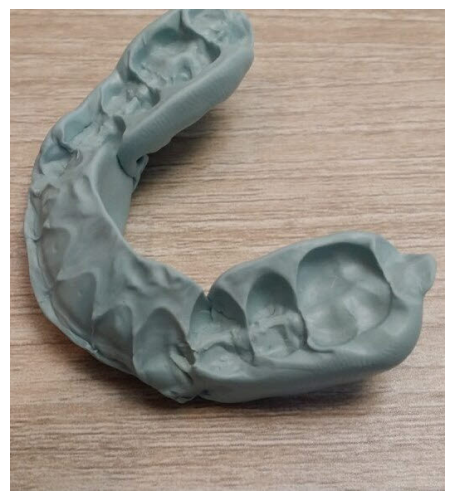

Fig. 3. Yinyang Balance Appliance.

Yianyang Balance Appliance made using Exofine Putty Type(GC corporation, Japan). 
Case 1
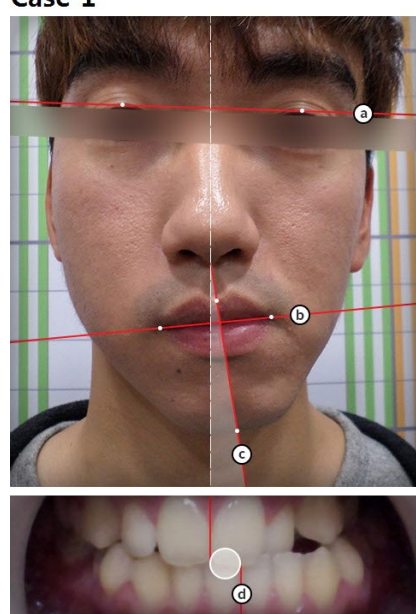

Case 3
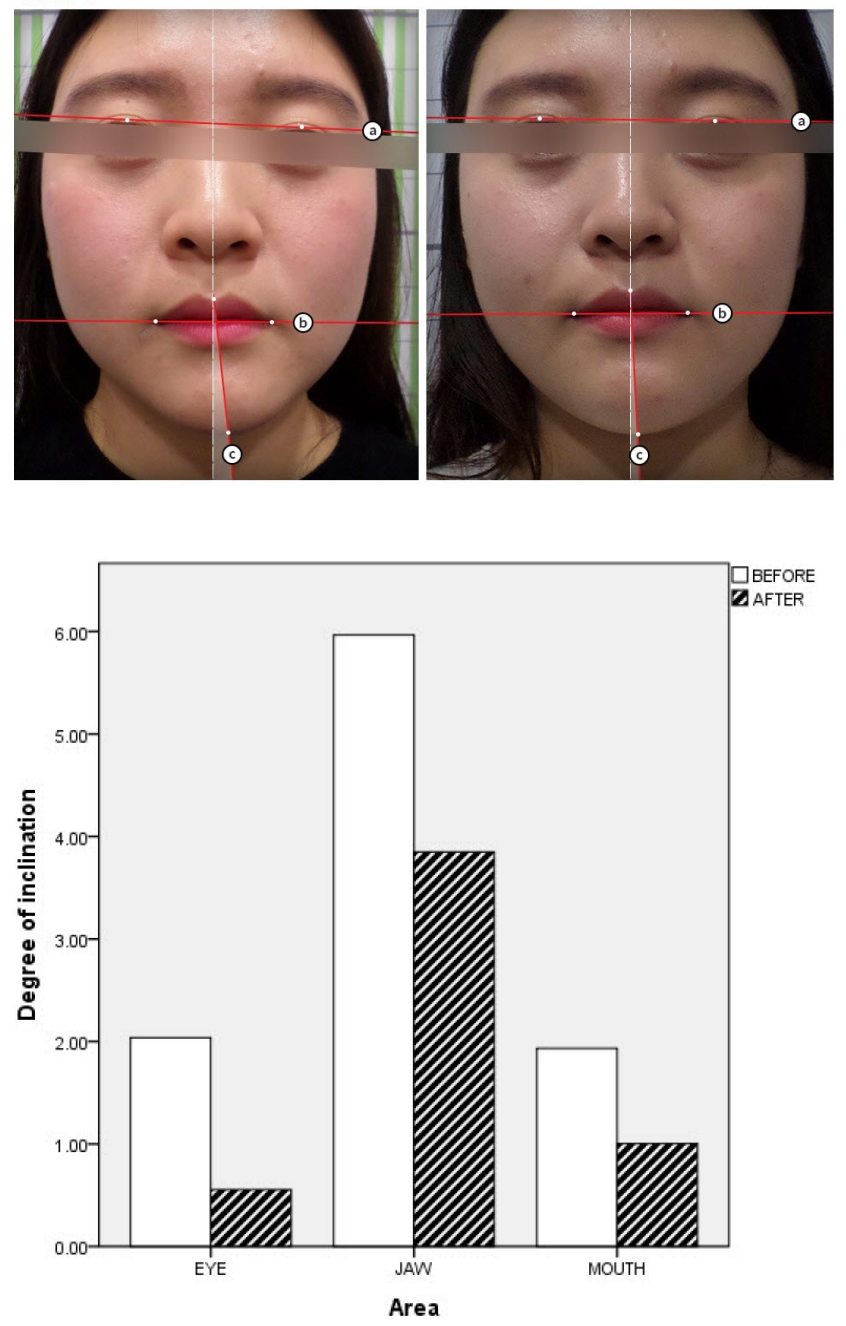

Fig. 5. Changes in Degree of Inclination after Korean Medicine Treatments.

The statistical significances of the correction effect for eye, jaw, and mouth are as follows: $p=0.109 ; p=0.109$; and $p=0.180$.
Case 2

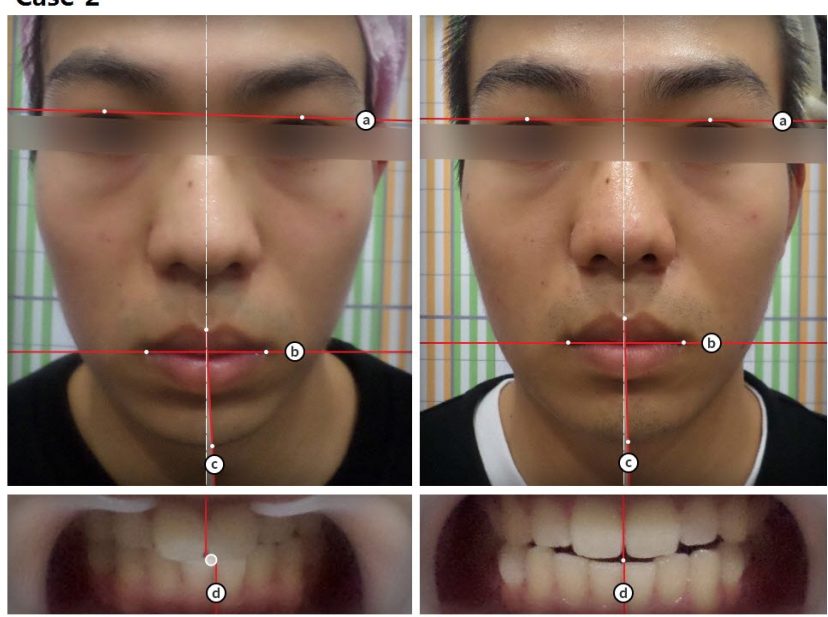

Fig. 4. Changes on Photos Before and After Treatment for Each Case. All patients received 12 sessions of Korean medicine treatments.

We analyzed the correction effect using SPSS version 22.0 for Windows(SPSS Inc., USA). Mean \pm standard deviation was calculated, and the statistical significance was tested by Wilcoxon signed rank test. $p$ value $<0.05$ was considered statistically significant.

The patients received twelve treatment sessions of MST and IASTM at intervals of 7 to 10 days, and wore YBA of FCST for about 4 hours every day during the treatment period. The average degree of inclination of eye, mouth and jaw were decreased: $2.04 \pm 0.47$ to $0.55 \pm 0.47 ; 1.93 \pm 3.06$ to $1.00 \pm 1.74$; and $5.97 \pm 3.10$ to $3.78 \pm 2.68$, respectively. The correction effects of KM treatments were $1.48 \pm 0.55,0.93 \pm 1.33$, and $2.12 \pm 1.17$, respectively(Fig. 4, 5). Despite these improvements, no statistical significance was observed(Table 2). Two patients with imbalance in the midline of mandibular teeth were found to be fully or partially corrected after treatments. There were no reports of adverse events other than mild bleeding, bruise, or erythema in all patients. 


\section{Discussion}

We report the effect and safety of KM treatments including MST, IASTM, and FCST on functional facial asymmetry. As results, eye, mouth and jaw of patients were corrected by $1.48 \pm 0.55,0.93 \pm 1.33$, and $2.12 \pm 1.17$ degree, respectively. No severe adverse events were occurred.

MST, performed when a patient visited a medical center, was effective in correcting unbalanced TMJ, and IASTM could also relieve facial asymmetry by alleviating stiffness and restriction of the soft tissue ${ }^{5,8)}$. The patient was constantly wearing YBA, a kind of dental patty, between treatments. We believe that this tool also had the effect of treating the asymmetry by correcting the imbalance of $\mathrm{TM}^{\mathrm{j}}$.

There are some limitations in this case report. This study

Table 1. Clinical Characteristics of the Three Patients

\begin{tabular}{lc}
\hline \multicolumn{2}{c}{ Patient characteristics } \\
\hline Sex(M/F) & $2 / 1$ \\
Age, year & $22.33(21 \sim 24)$ \\
Characteristics of facial asymmetry & \\
(1) side of mandibular lateral & Left side: 3 \\
displacement & Right side: 0 \\
(2) imbalance of eye & 3 \\
(3) imbalance of mouth & 2 \\
(4) imbalance of jaw & 3 \\
(5) imbalance of mandibular teeth & 2 \\
Treatment period, day & $102.33(91 \sim 110)$ \\
\hline
\end{tabular}

is a case report of a small number of patients. And there is a limit to the lack of objective evaluation indicators other than photographic data. Even though photography was taken with great care, the same lighting, the same expression, and the same angle could not be secured. Because the complex effects of the three treatments are described, the effects of individual treatments are not presented. Moreover, because definitive diagnostic criteria for functional facial asymmetry have not yet been established, in this case report, there is a limitation of the diagnosis which were presumed by clinician through the absence of dental and genital factors and the presence of mandibular displacement.

Despite these limitations, in the absence of a study on the effect of KM treatments for facial asymmetry, this case report is the first to introduce the effect of $\mathrm{KM}$ treatments. In addition, in order to objectify the degree of improvement of facial symmetry, an attempt was made to calculate the degree of inclination by numerical calculation. Although no statistical significance was found in this study, some improvement was observed in all patients. It is necessary to study the possibility of KM treatments for facial asymmetry in the future and we hope that this report can be used as basic data.

In conclusion, from September 2014 to September 2016, three patients with facial asymmetry were treated with KM treatments including MST, IASTM, and YBA of FCST. All subjects were improved after KM treatments on photos.

Table 2. Absolute Value of Degree of Inclination from Horizontal Line

\begin{tabular}{llccc}
\hline & & \multicolumn{2}{c}{ Absolute value of degree of inclination from horizontal line $\left(^{\circ}\right)$} \\
\cline { 3 - 5 } & & Eye & Mouth & Jaw \\
\hline Case 1(24/M) & 2014. 10. 31. & 2.01 & 5.46 & 9.12 \\
Case 2(21/M) & 2015. 02. 13. & 1.06 & 3.01 & 7.06 \\
& 2015. 03. 07. & 1.58 & 0 & 2.92 \\
Case 3(22/F) & 2015. 06. 05. & 0.13 & 0 & 1.94 \\
Mean value(mean \pm SD) & 2016. 02. 27 & 2.52 & 0.34 & 5.86 \\
& 2016. 06. 15. & 0.47 & 0 & 2.55 \\
Correction effect(mean $\pm S D)$ & Before treatment & $2.04 \pm 0.47$ & $1.93 \pm 3.06$ & $5.97 \pm 3.10$ \\
$p$ value & After treatment & $0.55 \pm 0.47$ & $1.00 \pm 1.74$ & $3.78 \pm 2.68$ \\
\hline
\end{tabular}

SD : standard deviation, ${ }^{*} p<0.05$ by Wilcoxon signed rank test.

All patients received 12 Korean medicine treatment sessions composed of Motion Style Treatment, Yinyang Balance Appliance of Functional Cerebrospinal Therapy, and Instrument Assisted Soft Tissue Mobilization. 
However no statistical significance was observed. There were no serious adverse events reported. This report was the first to suggest the possibility of $\mathrm{KM}$ treatments in correction of facial asymmetry. Given that many patients in Korea visit KM clinic for cosmetics, this study will be the first evidence to support the effect of KM treatments on facial asymmetry. Further well-designed, randomized, placebo-controlled trials are needed to verify these results, and these followings can be considered: the use of quantifiable scales is necessary to assess patient satisfaction and adverse events as well as asymmetric symptoms; standardized KM treatment procedures should be performed; and it is necessary to consider a more objective photographing method considering that the corrective effect of facial asymmetry is mainly evaluated through photographs.

\section{References}

1. Cheong YW, Lo LJ. Facial asymmetry: etiology, evaluation, and management. Chang Gung Med J. 2011 ; 34(4) : 341-51.

2. Bishara SE, Burkey PS, Kharouf JG. Dental and facial asymmetries: a review. Angle Orthod. 1994 ; 64(2) : 89-98.

3. Legrell PE, Isberg A. Mandibular length and midline asymmetry after experimentally induced temporomandibular joint disk displacement in rabbits. Am J Orthod Dentofacial Orthop. $1999 ; 115(3): 247-53$.

4. Thiesen G, Gribel BF, Freitas MP. Facial asymmetry: a current review. Dental Press J Orthod. 2015 ; 20(6) : 110-25.

5. Moon JY, Cho JH, Lee HE, Lim MJ, Kang I, Wang WH, et al. The Clinical Report on 3 cases of the patient of Tempormandibular Disorder Treated with Motion Style Treatment. J Korean Chuna Man Med Spine Nerves. 2008 ; 3(2) : 29-36.

6. Baker RT, Nasypany A, Seegmiller JG, Baker JG. Instrument-assisted soft tissue mobilization treatment for tissue extensibility dysfunction. Int J Athl Ther Training. 2013 ; 18(5) : 16-21.

7. Cheatham SW, Lee M, Cain M, Baker R. The efficacy of instrument assisted soft tissue mobilization: a systematic review. J Can Chiropr Assoc. 2016 ; 60(3) : 200-11.

8. Yin CS, Koh GW, Sohn KS, Lee JJ, Sohn IH, Lee YJ. A Torticollis Case Managed by Balance Appliance of FCST for the Meridian and Neurologic Balance. Korean J Acupunct. 2006 ; 23(1) : 120-2.

9. Ju JH, Lee KH, Kim DE, Jeong YN. USE OF OCCLUSAL SPLINT(ACTIVATOR) IN THE TREATMENT OF FACIAL ASYMMETRY. J Korean Acad Pediatr Dent. 2002 ; 29(3) : 313-7.

10. World Medical Association. World Medical Association Declaration of Helsinki: ethical principles for medical research involving human subjects. JAMA. 2013; 310(20) : 2191-4.

11. Jackson TH, Mitroff SR, Clark K, Proffit WR, Lee JY, Nguyen TT. Face symmetry assessment abilities: Clinical implications for diagnosing asymmetry. Am J Orthod Dentofacial Orthop. 2013 ; $144(5): 663-71$.

12. Canon EOS 5D. n.d. In Wikipedia. Retrieved September 15, 2017. Available from: URL: https://en.wikipedia.org/wiki/ Canon_EOS_5D

\section{국문초록}

목적 : 안면 비대칭에 대한 한의학적 치료의 적용가능성에도 불구하고, 아직까지 관련 연구는 보고되지 않고 있다. 이 증례보고에서 저자들은 하악골 측방변위로 인한 안면 비대칭에 대하여 한의학적 치료의 효과와 안전성을 보고하였다. 방법 : 3 명의 안면 비대칭 환자가 동작침법, 기능적 뇌척주요법의 음양균형장치, 연부조직이완술로 구성된 한의학적 치료를 12 회 받았다. 치료 전후에 환자의 사진이 촬영되었다. 치료 전후의 4 개의 주요 기준선의 변화가 평가되었다. 결과: 모든 환자들은 사진상의 호전을 보였다. 하지만 통계적으로 유의한 차이는 없었다. 결론 : 이 증례보고는 안면 비대칭에 대해 한의학적 치료의 효과를 보고하는 첫 번째 보고이다. 추후 이러한 결과를 확인하기 위한 더 잘 설계 된, 무작위화, 플라세보 대조 연구가 필요하다.

Key words : 침치료, 한의학, 안면 비대칭 